Vol. 7, No. 3, 2019, pp. 89-96

DOI: https://doi.org/10.29210/130700

Contents lists available at Jurnal IICET

Jurnal Konseling dan Pendidikan

ISSN: 2337-6740 (Print) ISSN: 2337-6880 (Electronic)

Journal homepage: http://jurnal.konselingindonesia.com

\title{
Hubungan antara kecerdasan emosional dan prestasi belajar dengan penggunaan social media pada siswa SMA
}

\author{
Mulawarman Mulawarman ${ }^{1}$, Fahmi Nuzulul $\mathrm{Huda}^{2}$, Suharso Suharso ${ }^{3}$, Muslikah Muslikah ${ }^{4}$ \\ ${ }^{1234}$ Fakultass Ilmu Pendidikan, Universitas Negeri Semarang
}

\begin{tabular}{l}
\hline Article Info \\
\hline Article history: \\
Received Aug $21^{\text {th }}, 2019$ \\
Revised Oct $11^{\text {th }}, 2019$ \\
Accepted Dec $30^{\text {th }}, 2019$
\end{tabular}

Keyword:

Social media

Emotional intelligence

Learning achievement

\begin{abstract}
This study aims to examine the correlation between emotional intelligence (EI) and learning achievement with social media usage on students. The kind of this research is correlation quantitative. Subjects were 4 of 10 schools with 226 students and using cluster random sampling and purposive sampling. The data were obtained by the questionnaire of social media usage, the scale of emotional intelligence (EI), and the ledger documentation. Validity rate on all of the instruments was high with the level of error $5 \%$, as well as the reliability of the instruments which was also high. The descriptive analysis using the mean and standard deviation, while hypothesis testing using the product moment correlation and multiple. The research results prove negative and significant relationship between EI with social media usage ( $\mathrm{rxy}=-0.251 ; \mathrm{p}$ $<0.05$ ). Furthermore, there is a significant negative correlation between the learning achievement and the social media usage $(\mathrm{rxy}=-0.429 ; \mathrm{p}<0.05)$. And there is a significant correlation between the emotional intelligence and learning achievement with social media usage $(\operatorname{ryx} 1 \times 2=0.472 \geq 0.138 ; \mathrm{p}$ $<0.05$ ). It can be concluded the higher EI and learning achievement, the lower social media usage among students, and otherwise. The variable EI and learning achievement give negative contribution towards the social media usage.
\end{abstract}

C 2019 The Authors. Published by Indonesian Institute for Counseling, Education and Therapy (IICET). This is an open access article under the CC BY license (https://creativecommons.org/licenses/by/4.0/)

\section{Corresponding Author:}

Mulawarman,

Email: muslikah@mail.unnes.ac.id

\section{Pendahuluan}

Internet merupakan media yang terus berkembang mengikuti perkembangan zaman. Dalam dunia pendidikan, istilah internet sudah tidak asing lagi di dengar. Penggunaan internet sudah sering digunakan untuk mencari atau memperoleh informasi akademik maupun non akademik, sehingga baik guru maupun siswa sering membuka beberapa situs di internet guna menunjang pembelajaran. Salah satu aktivitas yang sering dilakukan siswa ketika mengakses internet yaitu memanfaatkan penggunaan social media (media sosial) untuk mencari atau mendapatkan informasi, melakukan interaksi dengan orang lain dalam dunia maya, atau pun hanya sekedar sebagai hiburan mereka.

(Nasrullah, 2015)menjelaskan bahwa media sosial sebagai medium di internet yang memungkinkan pengguna merepresentasikan dirinya maupun berinteraksi, bekerjasama, berbagi, berkomunikasi dengan pengguna lain, dan membentuk ikatan sosial secara virtual. Semakin banyak vitur-vitur yang tersedia dalam social media, maka akan semakin menarik perhatian para siswa. Terdapat 6 kategori besar untuk melihat pembagian social media atau media sosial diantaranya adalah social networking, jurnal online, microblogging, media sharing, social bookmarking, dan wiki (Mayfield, 2008). Selain itu, menurut (A1Menayes, 2015) menjelaskan beberapa tujuan siswa menggunakan social media, antara lain entertainment, personal utility, information seeking, convenience dan altruism. Jika dilihat dari aspek intensitas penggunaan, maka ada 3 aspek yaitu berdasarkan frekuensi, durasi, dan situasi ketika menggunaan social media. 
Menurut survey yang telah dilakukan oleh Media Research Internet Study (Suryaningtyas, 2010) menyatakan bahwa $41 \%$ orang khususnya para remaja lebih memilih internet daripada televisi. Selain itu, data yang diperoleh dari Kemenkominfo pada tahun 2011 sebanyak 64\% pengguna jejaring sosial adalah usia remaja, dan mengalami peningkatan pada tahun 2014 sebesar 16\% menjadi 80\% remaja pengguna jejaring sosial. Jika ditinjau dari perkembangan usianya, remaja memiliki karakter yang kurang stabil seperti dalam hubungan interpersonal, pengelolaan kebutuhan hidup, pengembangan emosional dan kognitif, (Soliha, 2015). Menurut (Smahel et al., 2012), saat remaja mengalami kesulitan dalam perkembangannya, maka penggunaan internet menjadi lebih penting dibandingkan apa yang dilakukan orang lain pada umumnya, karena aktivitas online dapat memperluas dan memperkuat jaringan sosial mereka.

Siswa yang tidak mampu mengendalikan dirinya dalam penggunaan social media akan memiliki kecenderungan yang lebih rendah pada tingkat kecerdasan emosional. Sebagaimana yang dijelaskan oleh (Daniel Goleman, 1999) bahwa kemampuan dalam kecerdasan emosional mencakup pengendalian diri, semangat dan ketekunan, serta kemampuan untuk memotivasi diri sendiri. Kecerdasan emosional itu sendiri menurut (Cooper \& Sawaf, 2002) ialah kemampuan merasakan, memahami dan secara efektif menerapkan daya dan kepekaan emosi sebagai sumber energi, informasi, koneksi dan pengaruh yang manusiawi. Maka kecerdasan emosional adalah kemampuan seseorang dalam memantau, memahami, dan membedakan emosi yang dihasilkan baik dari diri sendiri maupun dari orang lain sehingga mampu menjalin hubungan yang lebih baik dengan pihak lain dan mampu mengarahkan pola pikir dan perilakunya. Terdapat 5 aspek yang ada dalam kecerdasan emosional, antara lain; individu mampu mengenali emosi diri, mampu mengelola emosi, mampu memotivasi diri sendiri, dapat mengenali emosi orang lain, dan dapat membina hubungan dengan orang lain, (D Goleman, 2005). Semakin tinggi kemampuan siswa dalam mengelola emosi diri, maka kehidupan efektif siswa akan semakin tercapai.

Kecerdasan emosional juga mempengaruhi aspek kognitif. Sehingga dalam ranah pendidikan, prestasi belajar dapat dipengaruhi pula oleh aspek kecerdasan emosional. Seperti yang diungkap oleh (Slameto, 2010), bahwa "intelegensi adalah salah satu faktor yang menentukan berhasil atau tidaknya siswa di sekolah". Prestasi belajar itu sendiri sebagai nilai yang merupakan bentuk perumusan akhir yang diberikan guru terkait dengan kemajuan atau prestasi belajar siswa selama waktu tertentu, (Suryabrata, 2002). Sehingga dapat disimpulkan bahwa prestasi belajar ialah hasil belajar yang telah dicapai siswa dalam jangka waktu tertentu yang lazim ditunjukkan melalui nilai rapor. Pencapaian prestasi belajar siswa merujuk kepada aspek-aspek kognitif, afektif dan psikomotor (Anitah, 2008).

Melihat fenomena penggunaan social media secara global, sebanyak 95\% remaja di Amerika dari usia 12 17 tahun sekarang sudah melakukan online dan $80 \%$ diantaranya remaja yang mengakses situs social media, (Lenhart et al., 2011). Selain itu, di Jepang sendiri menurut Kementerian Pendidikan Jepang memperkirakan terdapat kurang lebih 518.000 remaja mengalami kecanduan internet, (Soliha, 2015). Kemudian di Indonesia sendiri menurut Kementerian Komunikasi dan Informasi RI, pada tahun 2011 penggunaan internet pada remaja yang berusia 15-19 tahun menunjukkan angka sebesar 64\% dan semakin meningkat pada tahun 2014 menjadi $80 \%$ dengan jumlah pengguna internet mencapai 82 juta orang. (Young, 2004) mengungkapkan sebanyak 58\% siswa yang menggunakan internet secara berlebihan dapat mengakibatkan siswa menderita kebiasaan yang buruk, nilai yang buruk, atau gagal dalam sekolah. Artinya bahwa jika siswa memiliki tingkat penggunaan yang tinggi maka dapat mengakibatkan kecenderungan kecanduan internet khususnya pada penggunaan social media.

Sehubungan dengan penelitian terdahulu, hasil penelitian (Far et al., 2014) menunjukkan bahwa semua komponen kecerdasan emosional secara signifikan berkorelasi negatif terhadap kecanduan internet. Artinya bahwa semakin tinggi kecerdasan emosional seseorang maka kecanduan internet akan semakin berkurang, dan sebaliknya. Selain itu, hasil dari penelitian (Khoshakhlagh, Hasan., 2012) pun menunjukkan terdapat korelasi antara kecerdasan emosional dan gangguan mental dengan kecanduan internet. Dalam penelitian ini, kecemasan, obsesif-kompulsif, agresi, fobia, gangguan hipokondria, dan kecerdasan emosional adalah prediktor yang paling signifikan dari kecanduan internet.

Selanjutnya penelitian yang telah dilakukan oleh (Turel, 2015), serta (Hasnain, H., Nasreen, A., \& Ijaz, 2015) menjelaskan bahwa terdapat hubungan yang negatif antara tingkat kecanduan internet dengan keberhasilan akademik siswa. Hal ini menunjukkan bahwa semakin banyak siswa yang menghabiskan waktu di media sosial, maka akan semakin mempengaruhi IPK mereka. Selain itu, siswa yang cenderung kurang berpartisipasi dalam kelas pun akan lebih terlibat dalam menggunakan media sosial.

Dari hasil studi awal terkait dengan penelitian ini, diperoleh hasil yang cukup tinggi pada penggunaan social media di dua SMA Negeri di Kabupaten Purbalingga, yaitu 68,39\% dan 60,34\%. Sedangkan 
kecerdasan emosional siswa berada pada kecenderungan cukup rendah yaitu 54,67\% dan 48,5\%. Hal ini menunjukkan hampir seluruh siswa telah menggunakan social media, namun kurang di imbangi dengan tingkat kecerdasan emosional siswa yang dapat mengontrol diri mereka dalam penggunaannya.

Ketika siswa memiliki kecerdasan emosional yang kurang baik, maka perolehan prestasi belajarnya pun dapat menurun. Dalam kondisi ini, siswa sering kali merasa tidak nyaman atau mengalami stress akademik, sehingga salah satu cara untuk melakukan pelarian adalah dengan menggunakan social media sebagai salah satu cara untuk melakukan katarsis agar dapat merasa lebih nyaman. Dengan demikian, peran guru khususnya guru Bimbingan dan Konseling (BK) sangatlah dibutuhkan. Guru BK dapat memberikan layanan baik bersifat preventif, developmental, maupun kuratif untuk membantu para siswa yang telah mengalami permasalahan terkait dengan penggunaan social media atau pun untuk mencegah terjadinya dampak negatif dari social media serta untuk meningkatkan kecerdasan emosional dan prestasi belajar siswa melalui layanan berbagai layanan baik klasikal, kelompok, maupun individual.

Sehubungan dengan penjelasan mengenai penggunaan social media, kecerdasan emosional, dan prestasi belajar, maka penelitian ini bertujuan untuk menemukan tingkat penggunaan social media, kecerdasan emosional, dan prestasi belajar siswa, serta hubungan antar ketiga variabel yakni kecerdasan emosional, prestasi belajar, dan pengunaan social media pada siswa di SMA Negeri se-Kabupaten Purbalingga.

\section{Metode}

Metode penelitian ini menggunakan kuantitatif korelasional yang bertujuan untuk menemukan hubungan antar variabel. Sedangkan variabel yang digunakan adalah variabel independen (bebas) yaitu kecerdasan emosional (X1) dan prestasi belajar (X2), dan 1 variabel dependen (terikat) yakni penggunaan social media (Y). Subyek dalam penelitian ini adalah seluruh siswa SMA Negeri se-Kabupaten Purbalingga dengan jumlah 4137 siswa. Peneliti menggunakan cluster random sampling dan purposive sampling untuk menentukan jumlah sampel siswa masing-masing sekolah sehingga di dapat jumlah 226 siswa sebagai sampel penelitian. Instrumen yang digunakan peneliti berupa angket penggunaan social media, skala kecerdasan emosional, dan dokumentasi berupa leger. Validitas instrumen pada penelitian ini menggunakan construct validity serta content validity pada 30 siswa sebagai sampel dan diperoleh hasil yang tinggi untuk tingkat validitas masing-masing instrumen, serta untuk mengukur tingkat reliabilitas menggunakan rumus alpha cronbach dan di dapat pula tingkat reliabilitas yang tinggi yaitu diatas 0.7. analisis data menggunakan analisis deskriptif dan untuk menguji hipotesis menggunakan analisis product moment yaitu pada variabel kecerdasan emosional (X1) dengan penggunaan social media $(\mathrm{Y})$, dan prestasi belajar $(\mathrm{X} 2)$ dengan penggunaan social media $(\mathrm{Y})$. Sedangkan uji analisis korelasi ganda digunakan untuk menguji hubungan ketiga variabel secara bersamasama. Semua analisis dihitung menggunakan bantuan software SPSS versi 16.0.

\section{Hasil dan Pembahasan}

Berdasarkan hasil analisis deskriptif terkait dengan indikator penggunaan social media, kecerdasan emosional, dan prestasi belajar pada siswa di SMA Negeri se-Kabupaten Purbalingga, maka dapat diketahui melalui mean dan standar deviasi pada tabel 1,2, dan 3:

Tabel 1. Deskripsi Data Indikator Kecerdasan Emosional

\begin{tabular}{lcccc}
\hline \multicolumn{1}{c}{ Indikator } & $\mathrm{N}$ & Mean & SD & Kriteria \\
\hline Mengenal Emosi Diri & 226 & 3.324 & .473 & Sedang \\
Mengelola Emosi & 226 & 3.154 & .508 & Sedang \\
Memotivasi Diri & 226 & 2.428 & .335 & Rendah \\
Mengenal Emosi Orang Lain & 226 & 3.015 & .409 & Sedang \\
Membina Hubungan dengan Orang lain & 226 & 3.229 & .487 & Sedang \\
\hline TOTAL & 226 & 3.22 & .353 & Sedang \\
\hline
\end{tabular}


Tabel 2. Deskripsi Data Indikator Penggunaan Social Media

\begin{tabular}{|c|c|c|c|c|c|}
\hline Komponen & Indikator & $\mathrm{N}$ & Mean & SD & Kriteria \\
\hline \multirow{4}{*}{ Tujuan } & Entertainment & 226 & 3.572 & .668 & Tinggi \\
\hline & Personal utility & 226 & 3.829 & .579 & Tinggi \\
\hline & Information seeking & 226 & 3.902 & .626 & Tinggi \\
\hline & Altruism & 226 & 3.606 & .807 & Tinggi \\
\hline \multirow{4}{*}{ Intensitas penggunaan } & Frekuensi & 226 & 3.292 & .886 & Sedang \\
\hline & Durasi & 226 & 3.510 & .704 & Tinggi \\
\hline & Situasi & 226 & 2.705 & .705 & Sedang \\
\hline & TOTAL & 226 & 3.451 & .492 & Tinggi \\
\hline
\end{tabular}

Tabel 3 Deskripsi Data Indikator Prestasi Belajar

\begin{tabular}{lcccc}
\hline Indikator & $\mathrm{N}$ & Mean & SD & Keterangan \\
\hline Evaluasi sumatif & 226 & 74.44 & 7.07 & Belum Tuntas \\
\hline
\end{tabular}

Berdasarkan beberapa tabel 1, 2 dan 3, dapat diketahui secara keseluruhan penggunaan social media menunjukkan kecenderungan yang tinggi. Sedangkan tingkat kecerdasan emosional pada siswa memiliki kecenderungan yang sedang. Selain itu, hasil analisis deskriptif pada variabel prestasi belajar dengan menggunakan dokumentasi nilai leger semester ganjil atau gasal selama 1 semester menunjukkan kriteria belum tuntas, dimana nilai ini dibandingkan dengan nilai Kriteria Ketuntasan Minimal (KKM) yaitu 75.

Selanjutnya untuk menguji hipotesis hubungan antara kecerdasan emosional dengan penggunaan social media pada siswa menggunakan SPSS versi 16.0 diperoleh hasil:

Tabel 4. Hasil Uji Korelasi Kecerdasan Emosional dengan Penggunaan Social Media

\begin{tabular}{lcccc}
\hline \multicolumn{1}{c}{ Variabel } & N & Sig. & Kecerdasan emosional & Social media \\
\hline Kecerdasan emosional & 2 & 0,000 & 1 & -0.251 \\
Social media & 26 & 0,000 & -0.251 & 1 \\
\hline
\end{tabular}

Berdasarkan tabel 4, diketahui bahwa nilai rhitung $\geq$ rtabel $(p<0,05)$. Hal ini menunjukkan bahwa terdapat hubungan negatif dan signifikan antara variabel kecerdasan emosional dengan variabel penggunaan social media, namun hubungan kedua variabel tersebut lemah jika melihat dari interpretasi nilai r. Sedangkan variabel kecerdasan emosional memiliki sumbangan pengaruh sebesar 6,3\% pada variabel penggunaan social media dan sisanya dijelaskan oleh variabel lain. Artinya bahwa jika semakin tinggi kecerdasan emosional siswa, maka akan semakin rendah penggunaan social media siswa, dan sebaliknya. Jika semakin rendah kecerdasan emosional siswa, maka semakin tinggi tingkat penggunaan social media. Selanjutnya hasil uji hubungan antara variabel prestasi belajar dengan penggunaan social media memperoleh hasil sebagai berikut: 
Tabel 5. Hasil Uji Korelasi Prestasi Belajar dengan Penggunaan Social Media

\begin{tabular}{lcccc}
\hline \multicolumn{1}{c}{ Variabel } & $\mathrm{N}$ & Sig. & Prestasi belajar & Social media \\
\hline Prestasi belajar & 2 & 0,000 & 1 & -0.429 \\
Social media & 26 & 0,000 & -0.429 & 1 \\
\hline
\end{tabular}

Berdasarkan tabel 5, diketahui bahwa nilai rhitung $\geq$ rtabel $(\mathrm{p}<0,05)$. Hal ini menunjukkan bahwa terdapat hubungan negatif dan signifikan antara variabel prestasi belajar dengan penggunaan social media, dan hubungan kedua variabel tersebut yaitu cukup tinggi. Sedangkan variabel prestasi belajar memiliki sumbangan pengaruh sebesar $18,4 \%$ pada variabel penggunaan social media dan sisanya dijelaskan oleh variabel lain. Artinya bahwa jika semakin tinggi prestasi belajar siswa, maka akan semakin rendah penggunaan social media siswa, dan sebaliknya. Jika semakin rendah prestasi belajar siswa, maka semakin tinggi tingkat penggunaan social media. Kemudian hasil analisis hubungan antar ketiga variabel dapat dilihat pada tabel dibawah ini:

Tabel 6. Hasil Uji Korelasi Ganda antara Kecerdasan Emosional dan Prestasi Belajar dengan Penggunaan Social Media

\begin{tabular}{ccccc}
\hline Model & $\mathrm{R}$ & R Square & F & Sig. \\
\hline 1 & 0,472 & $22,27 \%$ & 31,91 & $0,000<0,005$ \\
\hline
\end{tabular}

Berdasarkan tabel 6 dapat diketahui bahwa hasil analisis data menunjukan koefisien korelasi ganda antara kecerdasan emosional dan prestasi belajar dengan penggunaan social media pada siswa SMA adalah Rhitung $\geq$ Rtabel, Fhitung $\geq$ Ftabel (Sig. $<$ Sig 0.05 ), sehingga menunjukkan bahwa terdapat hubungan yang signifikan antara kecerdasan emosional dan prestasi belajar dengan penggunaan social media pada siswa di SMA Negeri se-Kabupaten Purbalingga.

Berdasarkan hasil penelitian tentang hubungan antara kecerdasan emosional dan prestasi belajar dengan penggunaan social media pada siswa di SMA Negeri se-Kabupaten Purbalingga, maka diperoleh tingkat penggunaan social media yang tinggi. Artinya bahwa para siswa banyak yang menggunakan social media baik untuk tujuan hiburan, pencarian informasi akademik maupun non akademik, serta digunakan untuk kehidupan sosialnya. Hal ini sejalan dengan konsep (Al-Menayes, 2015) yang mengungkapkan bahwa siswa telah menggunakan berbagai macam jenis social media untuk berbagai macam tujuan, seperti mencari hiburan, memenuhi kebutuhan dalam mencari informasi, berkomunikasi dengan orang lain, serta memanfaatkan social media untuk membantu orang lain (bersikap altruism).

Selain itu, pada kecerdasan emosional siswa secara keseluruhan memiliki kecenderungan yang sedang. Artinya bahwa para siswa telah memiliki tingkat kecerdasan emosional yang cukup dan mereka masih bisa ditingkatkan kembali dengan berbagai latihan agar dapat mengelola emosinya dengan lebih efektif. Sedangkan perolehan hasil pada prestasi belajar siswa secara keseluruhan, mereka masih berada pada kategori belum tuntas. Hal ini dapat disebabkan karena beberapa faktor baik secara internal maupun eksternal, (Slameto, 2010). Salah satu faktor internal yang memiliki kecenderungan mempengaruhi prestasi belajar adalah faktor psikologis yaitu intelegensi, perhatian, minat, kematangan, dan kesepian yang dapat mempengaruhi rendahnya prestasi belajar siswa. Faktor yang kedua adalah faktor kelelahan baik kelelahan secara jasmani maupun rohani. Jam sekolah yang lama membuat para siswa merasa lelah jasmani sehingga hal ini berpengaruh pada jam belajar dan jam istirahat siswa di rumah. Sedangkan faktor eksternal yang dapat mempengaruhi prestasi belajar meliputi kondisi keluarga, sekolah, dan masyarakat.

Berdasarkan analisis hubungan antar variabel, hasil dari penelitian ini menunjukan bahwa terdapat hubungan negatif dan signifikan antara kecerdasan emosional dangan penggunaan social media pada siswa di SMA Negeri se-Kabupaten Purbalingga. Hasil penelitian ini selaras dengan konsep (Far et al., 2014); (Hamissi et al., 2013); serta (Khoshakhlagh, Hasan., 2012) yang menjelaskan bahwa terdapat hubungan negatif dan signifikan antara kecanduan internet dengan tingkat kecerdasan emosional. Temuan ini menunjukkan bahwa siswa yang memiliki kecerdasan emosional tinggi, maka dalam penggunaan internet lebih mampu menggunakannya dengan baik sehingga tidak sampai terjadi kecanduan internet atau internet 
addiction. Sebaliknya, jika mereka memiliki kecerdasan emosional yang rendah, maka tingkat penggunaan internet akan semakin tinggi yang dapat menyebabkan kecenderungan kecanduan internet.

Demikian halnya dengan hasil penelitian mengenai prestasi belajar dan penggunaan social media bahwa terdapat hubungan yang negatif dan signifikan antara prestasi belajar dengan penggunaan social media. Hal ini sesuai dengan konsep dari beberapa penelitian yang menunjukkan bahwa terdapat hubungan yang negatif antara tingkat kecanduan pada internet dengan keberhasilan akademik siswa Sekolah Menengah, (Gaol \& Riady, 2012). Penelitian ini menjelaskan bahwa ketika keberhasilan akademik siswa meningkat, maka ratarata kecanduan internet pada siswa menurun, begitu pula sebaliknya.

Hasil penelitian yang telah dilakukan oleh peneliti maupun hasil dari penelitian terdahulu menunjukkan bahwa kecerdasan emosional dan prestasi belajar siswa SMA memiliki hubungan yang cukup kuat dan signifikan dalam mempengaruhi penggunaan social media siswa sehari-hari. Artinya semakin tinggi kecerdasan emosional maupun prestasi belajar yang ada dalam diri siswa, maka mereka akan semakin rendah dalam menggunakan social media. Sedangkan jika kecerdasan emosional dan prestasi belajar siswa menurun maka penggunaan social media siswa akan lebih meningkat.

Social media itu sendiri adalah alat yang memungkinkan pengguna berinteraksi, bekerjasama, berbagi, berkomunikasi dengan pengguna lain, dan membentuk ikatan sosial secara virtual, (Nasrullah, 2015). Menurut (Young, 1999), terdapat faktor yang mempengaruhi siswa menggunakan social media, salah satunya adalah emotion dan kognition. Dalam hal ini, emotion dikaitkan dengan kecerdasan emosional yang dimiliki oleh siswa, sedangkan faktor cognition adalah prestasi belajar yang diperoleh siswa selama kurun waktu tertentu. Ketika siswa belum mampu mengolah kecerdasan emosional yang ada dalam diri, maka mereka memiliki kecenderungan yang lebih tinggi pada peningkatan penggunaan social media. Begitu pula dengan prestasi belajar yang diperoleh siswa. Mereka yang memiliki rata-rata rendah atau belum tuntas secara KKM, mayoritas memiliki tingkat penggunaan social media yang lebih tinggi dibandingkan dengan siswa yang memiliki tingkat prestasi belajar yang baik di kelas. Hal ini dikarenakan siswa tidak mampu mengontrol dirinya dalam mengakses social media sehingga dalam proses KBM pun terganggu.

Kecerdasan emosional dan prestasi belajar memiliki hubungan yang cukup kuat dan signifikan pada variabel penggunaan social media. Artinya bahwa terdapat variabel atau komponen lain yang juga samasama mempengaruhi tingginya tingkat penggunaan social media pada siswa. Menurut (Young, 1999) terdapat 4 faktor yang mempengaruhi penggunaan social media, antara lain faktor application, emotions, cognition, dan life events. Emotions atau dalam hal ini adalah kecerdasan emosional dan cognition adalah prestasi belajar memiliki hubungan yang cukup, sehingga komponen lain yang dapat berpengaruh pada penggunaan social media seperti application atau aplikasi dan juga life events. Aplikasi yang menarik perhatian para siswa pun dapat membuat siswa lebih fokus pada dunia maya khususnya di social media. Hal ini terbukti pada penggunaan jenis social media yang tinggi, dimana hampir seluruh siswa telah menggunakan berbagai jenis social media.

Selain itu, faktor life events atau kejadian dalam kehidupan siswa yang kurang menyenangkan membuat siswa mencari pelampiasan pada kehidupan yang lebih nyaman seperti berinteraksi atau mencari kesenangan melalui social media. Begitu pula ketika siswa merasa kesepian, mereka akan mencari kegiatan yang membuatnya lebih berarti. Selaras dengan pendapat (Rosdaniar, 2008) yang menjelaskan bahwa adanya pengaruh kesepian pada kecanduan internet dikarenakan kesepian menjadi salah satu faktor pendukung timbulnya perilaku kecanduan internet. Menurut Anderson, et al., (Rosdaniar, 2008), orang yang mengalami kecanduan internet adalah orang yang mengatur perasaannya (mood) dengan berinternet agar dapat keluar dari berbagai tekanan, meningkatkan perasaan ketika merasa lemah, cemas atau merasa terisolasi.

Oleh sebab itu, mengetahui tingkat penggunaan social media yang tinggi di kalangan siswa SMA Negeri se-Kabupaten Purbalingga, membuat para guru dan orang tua harus lebih mengawasi kegiatan apa saja yang dilakukan siswa ketika mengakses social media. Tingginya tingkat penggunaan social media dikhawatirkan dapat berdampak pada psikis siswa sehingga mereka memiliki kecenderungan kecanduan social media. Namun hal ini dapat dicegah, salah satu caranya adalah dengan lebih meningkatkan kecerdasan emosional dan prestasi belajar siswa sehingga mereka lebih mampu mengontrol atau mengendalikan diri dalam penggunaanya. Guru Bimbingan dan Konseling (BK) dapat memberikan berbagai layanan baik itu yang bersifat preventif maupun kuratif pada siswa pengguna social media. Selain itu, guru BK dapat pula meningkatkan kecerdasan emosional dan prestasi belajar siswa dengan layanan klasikal, kelompok, atau pun individual mengingat kecerdasan emosional dan prestasi belajar memiliki pengaruh yang cukup kuat pada tingkat penggunaan social media. Dengan demikian siswa dapat membentuk kehidupan yang lebih efektif. 


\section{Kesimpulan}

Dari hasil penelitian yang telah dilakukan, maka dapat disimpulkan bahwa secara umum deskripsi tentang penggunaan social media siswa memiliki kecenderungan yang tinggi, tingkat kecerdasan emosional siswa memiliki kecenderungan yang sedang, serta tingkat prestasi belajar siswa secara keseluruhan masih memiliki kategori belum tuntas. Sedangkan hubungan antar variabel memperoleh hasil bahwa terdapat hubungan yang negatif dan signifikan antara kecerdasan emosional siswa dengan penggunaan social media siswa, serta terdapat hubungan yang negatif dan signifikan antara prestasi belajar dengan penggunaan social media pada siswa di SMA Negeri se-Kabupaten Purbalingga. Oleh sebab itu, secara keseluruhan terdapat hubungan yang signifikan antara kecerdasan emosional dan prestasi belajar dengan penggunaan social media pada siswa di SMA Negeri se-Kabupaten Purbalingga. Hal ini berarti bahwa semakin tinggi tingkat kecerdasan emosional dan prestasi belajar siswa, maka tingkat penggunaan social media siswa semakin rendah. Sedangkan jika kecerdasan emosional dan prestasi belajar siswa memiliki kecenderungan yang lebih rendah, maka tingkat penggunaan social media siswa memiliki kecenderungan yang lebih tinggi. Bagi peneliti berikutnya yang tertarik untuk melakukan pengembangan penelitian mengenai hubungan antara kecerdasan emosional dan prestasi belajar dengan penggunaan social media, maka dapat mengkaji lebih dalam aspek-aspek yang mempengaruhi prestasi belajar terhadap penggunaan social media melihat hubungan kedua variabel tersebut cukup kuat dan aspek lain yang memiliki kecenderungan mempengaruhi tingkat penggunaan social media adalah aspek applications dan life events. Selain itu, diharapkan bahwa penelitian tidak hanya terhenti untuk mengetahui hubungan antar variabel, akan tetapi dilanjutkan dengan pemberian treatment atau dikembangkan menjadi penelitian eksperimen.

\section{Referensi}

Al-Menayes, J. J. (2015). Motivations for using social media: An exploratory factor analysis. International Journal of Psychological Studies, 7(1), 43.

Anitah, S. (2008). Strategi Pembelajaran di SD. Universitas Terbuka.

Cooper, R. K., \& Sawaf, A. (2002). Kecerdasan Emosional dalam Kepemimpinan dan Organisasi. Jakarta: PT Gramedia Pustaka Utama, Terjemahan Alex Tri Kancono.

Far, N. S., Samarein, Z. A., Yekleh, M., Tahmasebi, S., \& Yaryari, F. (2014). Relationship between the components of emotional intelligence and internet addiction of students in Kharazmi University. Int $J$ Psychol Behav Res, 3(1), 60-66.

Gaol, M. L., \& Riady, H. (2012). 153 Kinerja, Budaya Organisasi dan Gaya Kepemimpinan: Studi pada SMA Swasta DKI Jakarta. Jurnal Ilmu Manajemen, 1(2), 32-45.

Goleman, D. (2005). Kecerdasan emosional.(penerjemah: Hermaya T.). Jakarta, ID: Gramedia Pustaka Utama.

Goleman, Daniel. (1999). Working With Emotional Intelligence. Bloomsbury Publishing Plc.

Hamissi, J., Babaie, M., Hosseini, M., \& Babaie, F. (2013). The relationship between emotional intelligence and technology addiction among university students. International Journal of Collaborative Research on Internal Medicine \& Public Health, 5(5), 0.

Hasnain, H., Nasreen, A., \& Ijaz, H. (2015). Impact of Social Media Usage on Academic Performance of University Students. 2nd International Research Management \& Innovation Conference (Irmic 2015), Langkawi, 26-27 Agustus 2015.

Khoshakhlagh, Hasan., \& S. F. (2012). Original Article: The Relationship of Emotional Intelligence and Mental Disorders with Internet Addiction in Internet Users University Students. Addict Health, Summer \& Autumn, 4(3-4), 133-141.

Lenhart, A., Madden, M., Smith, A., Purcell, K., Zickuhr, K., \& Rainie, L. (2011). Teens, Kindness and Cruelty on Social Network Sites: How American Teens Navigate the New World of" Digital Citizenship". Pew Internet \& American Life Project.

Mayfield, A. (2008). What is Social Media? icrossing. co. uk/ebooks. Erişim Tarihi, $20,2012$.

Nasrullah, R. (2015). Media sosial: Perspektifkomunikasi, budaya, dan sosioteknologi. Simbiosa Rekatama Media.

Rosdaniar. (2008). Hubungan antara Kesepian dengan Kecanduan Internet (Internet Addiction Disorder) pada Mahasiswa. Universitas Islam Indonesia.

Slameto. (2010). Belajar dan Faktor-faktor yang Mempengaruhi. Rineka Cipta.

Smahel, D., Brown, B. B., \& Blinka, L. (2012). Associations between online friendship and Internet addiction among adolescents and emerging adults. Developmental Psychology, 48(2), 381.

Soliha, S. F. (2015). Tingkat ketergantungan pengguna media sosial dan kecemasan sosial. Interaksi: Jurnal Ilmu Komunikasi, 4(1), 1-10. 
Suryabrata, S. (2002). Psikologi Pendidikan. Raja Grafindo Persada.

Suryaningtyas, D. (2010). Upaya Meningkatkan Berpikir Kreatif Melalui Layanan Penguasaan Konten Berbantuan Mind Map Pada Siswa Kelas X SMA NU Al Ma'ruf Kudus. UNIVERSITAS MURIA KUDUS.

Turel, Y. K. \& M. T. (2015). The Relationship between Internet Addiction and Academic Success of Secondary School Students. Anthropologist, 20(12), 280-288.

Young, K. S. (1999). Internet addiction: symptoms, evaluation and treatment. Innovations in Clinical Practice: A Source Book, 17(17), 351-352.

Young, K. S. (2004). Internet addiction: A new clinical phenomenon and its consequences. American Behavioral Scientist, 48(4), 402-415. 